\title{
Effect of abrupt weaning at housing on leukocyte distribution, functional activity of neutrophils, and acute phase protein response of beef calves
}

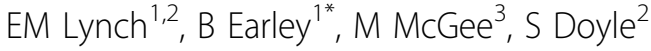

\begin{abstract}
Background: Sixteen, spring-born, single suckled, castrated male calves of Limousin $\times$ Holstein-Friesian and Simmental $\times$ Holstein-Friesian dams respectively, were used to investigate the effect of weaning on total leukocyte and differential counts, neutrophil functional activity, lymphocyte immunophenotypes, and acute phase protein response. Calves grazed with their dams until the end of the grazing season when they were housed in a slatted floor shed. On the day of housing, calves were assigned to a treatment, (i) abruptly weaned (W: $n=8$ ) or (ii) nonweaned (controls) ( $C: n=8)$. Weaned calves were housed in pens without their dams, whereas non-weaned (control) calves were housed with their dams. Blood was collected on day -7, 0 (housing), 2, 7, and 14 to determine total leukocyte and differential counts and concentration of fibrinogen and haptoglobin. Lymphocyte immunophenotypes were characterised using selected surface antigens $\left(\mathrm{CD}^{+}, \mathrm{CD}^{+}, \mathrm{WC}^{+}(\gamma \delta \mathrm{T}\right.$ cells), $\mathrm{MHC}$ Class $\mathrm{II}^{+}$lymphocytes), and the functional activities of neutrophils (surface expression of L-selectin (CD62L), phagocytic and oxidative burst activity) were investigated using flow cytometry.

Results: Treatment $\times$ sampling time interactions $(P<0.05)$ were detected for total leukocyte and neutrophil counts, all lymphocyte subsets, mean fluorescence intensity of $\mathrm{CD}_{2} 2 \mathrm{~L}^{+}$neutrophils, and percentage neutrophils performing phagocytosis. On d 2, total leukocyte and neutrophil count increased $(P<0.001)$, and percentage CD4 ${ }^{+}$ and $\mathrm{CD}^{+}$lymphocytes, percentage phagocytic neutrophils, mean fluorescence intensity of $\mathrm{CD}^{2} 2 \mathrm{~L}^{+}$neutrophils decreased $(P<0.05)$ in $W$ compared with baseline $(d 0)$, whereas they were unchanged $(P>0.05)$ in $C$. On $d 2$, percentage $\mathrm{WC}^{+}$lymphocytes decreased $(P<0.05)$, whereas percentage MHC class $\mathrm{II}^{+}$lymphocytes increased $(P<$ 0.05) in $W$ and $C$, however the magnitude of change was greater in $W$ than $C$. There were no treatment $x$ sampling time interactions $(P>0.05)$ for monocyte, eosinophil, and basophil counts, percentage $\mathrm{G}^{+}$neutrophils, or percentage oxidative burst positive neutrophils.

Conclusions: Abrupt weaning resulted in increased neutrophil counts and impaired trafficking and phagocytic function. Together with the changes in lymphocyte subsets, the results suggest that there was a greater transitory reduction in immune function at housing in abruptly weaned than non-weaned beef calves.
\end{abstract}

\section{Background}

Weaning is an inherent husbandry practice in cow-calf beef production systems that imposes physical, psychological, and nutritional stressors on calves. Integrated calf-to-beef production systems, such as seasonal grassbased systems, often combine weaning and housing [1], whereas non-integrated systems often combine weaning with additional stressors such as transportation and

\footnotetext{
* Correspondence: bernadette.earley@teagasc.ie

${ }^{1}$ Animal and Bioscience Research Department, Animal \& Grassland Research and Innovation Centre, Teagasc, Grange, Dunsany, Co Meath, Ireland
}

marketing, prior to entry into feedlots [2]. Following abrupt weaning, beef calves exhibit distress behaviours $[3,4]$, with alterations in hormonal mediators of stress [5,6] and immune function [7-9] evident up to $7 \mathrm{~d}$ postweaning. Furthermore, weaning is considered to be a predisposing factor to bovine respiratory disease (BRD) $[10,11]$.

Neutrophils provide the first line of cellular defence against pathogens, whereas lymphocytes are of pivotal importance in cell-mediated and humoral immunity $[12,13]$. Although studies have examined neutrophil and

\section{C) Biomed Central}


lymphocyte function and distribution following transport $[14,15]$, and during natural and experimental cases of BRD [16-18], none have investigated the direct effects of weaning on these immune variables in beef calves. Additional information on the immune status of newly weaned calves at a time when pathogen exposure is heightened may be useful for identifying animals likely to succumb to infection.

Thus, the objectives of the study were to examine the effect of abrupt weaning at housing on i) peripheral leukocyte and differential counts, ii) granulocyte positive neutrophils and lymphocyte immunophenotypes, iii) phagocytic and oxidative burst activity, and surface expression of CD62L of neutrophils, and iv) the acute phase protein response in beef calves.

\section{Results}

\section{Rectal body temperature}

There was no effect of treatment $(P=0.4)$ or treatment $\times$ sampling time interaction $(P=0.3)$, for rectal body temperature whereas sampling time was significant $(P=$ 0.048) (data not shown). Rectal body temperature increased $(P=0.02)$ on d 2 (mean (s.e.) $38.9(0.09){ }^{\circ} \mathrm{C}$ ), and subsequently did not differ $(P>0.05)$ compared with baseline (d 0; mean (s.e) $\left.38.5(0.07){ }^{\circ} \mathrm{C}\right)$.

\section{Total leukocyte and differential counts}

There was a treatment $\times$ sampling time interaction $(P=$ 0.01 ) for total leukocyte count whereby on $\mathrm{d} 2$ it increased $(P=0.004)$ in $\mathrm{W}$ and returned to baseline, whereas $C$ did not differ $(P=0.9)$ from baseline (Table $1)$. There were treatment $\times$ sampling time interactions for neutrophil $(P<0.0001)$ and lymphocyte $(P=0.002)$ counts (Table 1). On d 2, neutrophil count increased $(P$ $<0.0001)$ and lymphocyte counts decreased $(P=0.008)$ in $\mathrm{W}$, whereas $\mathrm{C}$ did not differ from baseline (Table 1). There were no effects $(P>0.05)$ of treatment and sampling time, or treatment $\times$ sampling time interactions for monocyte, eosinophil and basophil counts (Table 1).

\section{Granulocyte-positive cells}

There was no effect of treatment $(P=0.1)$ or treatment $\times$ sampling time interaction $(P=0.2)$ for percentage of $\mathrm{Gl}^{+}$ neutrophils but sampling time was significant $(P<$ $0.0001)$. On $\mathrm{d} 2$, the percentage of $\mathrm{G1}^{+}$neutrophils it increased $(P<0.001$, mean (s.e.) $48.5(1.71) \mathrm{MFI}))$ and subsequently returned to baseline (mean (s.e) 37.3 (1.7) MFI) by d 7 (Table 2).

\section{Neutrophil functional activity}

There was a treatment $\times$ sampling time interaction $(P=$ 0.002) for MFI of CD62 $\mathrm{L}^{+}$neutrophils (Table 2). On d 2 , MFI decreased $(P=0.002)$ in $\mathrm{W}$ and subsequently returned to baseline, whereas $C$ did not differ $(P=0.9)$ from baseline. There was a treatment $\times$ sampling time interaction $(P=0.02)$ for percentage phagocytosing neutrophils (Table 3 ). On d 2, percentage neutrophils performing phagocytosis decreased in $\mathrm{W}(P<0.01)$, whereas $C$ did not differ $(P=0.4)$ compared with baseline and subsequently, they returned to baseline $(P>$

Table 1 Effect of abrupt weaning at housing on total leukocyte and differential counts in beef calves

\begin{tabular}{|c|c|c|c|c|c|c|c|c|c|}
\hline \multirow[b]{2}{*}{$\begin{array}{l}\text { Cell type } \\
\left(\times 10^{3} \text { cells } / \mu \mathrm{L}\right)\end{array}$} & & \multicolumn{5}{|c|}{ Day (d) relative to housing } & \multicolumn{3}{|c|}{$P$-values ${ }^{1}$} \\
\hline & & -7 & $0^{2}$ & 2 & 7 & 14 & $T$ & $\mathrm{~S}$ & $\mathrm{~T} \times \mathrm{S}$ \\
\hline \multirow[t]{2}{*}{ Total leukocytes } & $C$ & $10.3 \pm 0.61$ & $10.5 \pm 0.31$ & $10.8^{x} \pm 0.47$ & $10.5 \pm 0.92$ & $10.3 \pm 0.32$ & 0.03 & 0.0005 & 0.01 \\
\hline & W & $10.6 \pm 0.62$ & $10.3^{\mathrm{a}} \pm 0.31$ & $13.3^{b, c, y} \pm 0.47$ & $11.2^{a, c} \pm 0.92$ & $10.2^{\mathrm{a}} \pm 0.32$ & & & \\
\hline \multirow[t]{2}{*}{ Neutrophils } & C & $2.8 \pm 0.11$ & $2.9 \pm 0.17$ & $\begin{aligned} & 3.2^{x} \\
\pm & 0.65\end{aligned}$ & $2.9 \pm 0.64$ & $2.5 \pm 0.23$ & 0.006 & $<0.0001$ & $<0.0001$ \\
\hline & W & $2.7 \pm 0.11$ & $2.5^{a} \pm 0.18$ & $6.6^{b, y} \pm 0.68$ & $2.7^{a} \pm 0.64$ & $2.7^{a} \pm 0.24$ & & & \\
\hline \multirow[t]{2}{*}{ Lymphocytes } & C & $7.0 \pm 0.19$ & $6.7 \pm 0.21$ & $\begin{array}{c}6.6^{x} \pm \\
0.22\end{array}$ & $6.8 \pm 0.49$ & $6.9 \pm 0.36$ & 0.3 & 0.0006 & 0.002 \\
\hline & W & $6.9 \pm 0.19$ & $6.9^{a} \pm 0.22$ & $5.2^{b, y} \pm 0.22$ & $7.3^{a} \pm 0.49$ & $6.7^{a} \pm 0.37$ & & & \\
\hline \multirow[t]{2}{*}{ Monocytes } & C & $0.64 \pm 0.10$ & $0.46 \pm 0.05$ & $0.59 \pm 0.07$ & $0.54 \pm 0.11$ & $0.47 \pm 0.05$ & 0.5 & 0.1 & 0.16 \\
\hline & W & $0.60 \pm 0.11$ & $0.48 \pm 0.06$ & $0.59 \pm 0.06$ & $\begin{array}{r}0.59 \\
\pm 0.10\end{array}$ & $0.50 \pm 0.05$ & & & \\
\hline \multirow[t]{2}{*}{ Eosinophils } & C & $0.29 \pm 0.05$ & $0.33 \pm 0.10$ & $0.31 \pm 0.12$ & $0.59 \pm 0.11$ & $0.35 \pm 0.07$ & 0.3 & 0.06 & 0.4 \\
\hline & W & $0.21 \pm 0.05$ & $0.31 \pm 0.11$ & $0.38 \pm 0.13$ & $0.29 \pm 0.10$ & $0.24 \pm 0.07$ & & & \\
\hline \multirow[t]{2}{*}{ Basophils } & C & $0.12 \pm 0.02$ & $0.15 \pm 0.02$ & $0.13 \pm 0.01$ & $0.11 \pm 0.02$ & $0.12 \pm 0.01$ & 0.6 & 0.5 & 0.8 \\
\hline & W & $0.11 \pm 0.02$ & $0.12 \pm 0.02$ & $0.12 \pm 0.01$ & $0.11 \pm 0.02$ & $0.13 \pm 0.01$ & & & \\
\hline
\end{tabular}

${ }^{1} \mathrm{~T}=$ treatment, $\mathrm{S}=$ sampling time, $\mathrm{T} \times \mathrm{S}=$ treatment $\times$ sampling time interactions

$\mathrm{W}=$ abruptly weaned, $\mathrm{C}=$ non-weaned (control) calves.

$a, b$, CWithin a row, least squares means without a common superscript differ $(P<0.05)$.

$\mathrm{x}, \mathrm{y}$ Within a column (day) for each variable, least squares means without a common superscript differ $(P<0.05) .{ }^{2}$ Baseline is defined as $\mathrm{d} 0$ for each variable. Data presented are least squares means \pm s.e.m. 
Table 2 Effect of abrupt weaning at housing on percentage $\mathrm{G1}^{+}$neutrophils and $\mathrm{CD}^{+} \mathrm{LL}^{+}$neutrophils $\mathrm{MFI}^{1}$ in beef calves

\begin{tabular}{|c|c|c|c|c|c|c|c|c|c|}
\hline \multirow[b]{2}{*}{ Neutrophils } & & \multicolumn{5}{|c|}{ Day (d) relative to housing } & \multicolumn{3}{|c|}{$P$-values ${ }^{2}$} \\
\hline & & -7 & $0^{2}$ & 2 & 7 & 14 & $T$ & $S$ & $\mathrm{~T} \times \mathrm{S}$ \\
\hline \multirow[t]{2}{*}{$\overline{\mathrm{G} 1^{+}, \%}$} & $C$ & $27.6 \pm 0.68$ & $27.3^{\mathrm{a}} \pm 0.83$ & $35.0^{b, c, x} \pm 0.77$ & $30.8^{\mathrm{a}, c} \pm 0.84$ & $27.7^{\mathrm{a}} \pm 0.85$ & 0.1 & $<0.0001$ & 0.2 \\
\hline & W & $28.9 \pm 0.68$ & $27.4^{\mathrm{a}} \pm 0.83$ & $41.9^{b, y} \pm 0.77$ & $31.4^{\mathrm{a}} \pm 0.84$ & $28.2^{\mathrm{a}} \pm 0.85$ & & & \\
\hline \multirow[t]{2}{*}{$\mathrm{CD} 6 \mathrm{~L}^{+}, \mathrm{MFI}^{1}$} & C & $120.9 \pm 1.81$ & $121.1 \pm 1.91$ & $119.8^{x} \pm 2.31$ & $122.3 \pm 2.02$ & $120.4 \pm 1.49$ & 0.1 & $<0.0001$ & 0.002 \\
\hline & W & $122.6 \pm 1.81$ & $122.2^{\mathrm{a}} \pm 1.91$ & $107.0^{b, y} \pm 2.31$ & $119.3^{\mathrm{a}} \pm 2.02$ & $121.3^{\mathrm{a}} \pm 1.49$ & & & \\
\hline
\end{tabular}

${ }^{1} \mathrm{MFI}=$ mean fluorescence intensity

${ }^{2} \mathrm{~T}=$ treatment, $\mathrm{S}=$ sampling time, $\mathrm{T} \times \mathrm{S}=$ treatment $\times$ sampling time interactions

$\mathrm{W}=$ abruptly weaned, $\mathrm{C}=$ non-weaned (control) calves.

$\mathrm{a}, \mathrm{b}, \mathrm{c}$ Within a row, least squares means without a common superscript differ $(P<0.05)$.

$x, y$ Within a column (day) for each variable, least squares means without a common superscript differ $(P<0.01) .{ }^{2}$ Baseline is defined as $d 0$ for each variable. Data presented are least squares means \pm s.e.m.

$0.05)$. There was no effect of treatment $(P=0.2)$ and sampling time $(P=0.5)$, or treatment $\times$ sampling time interaction $(P=0.7)$ for the percentage neutrophils positive for oxidative burst activity (Table 3 ).

\section{Lymphocyte immunophenotypes}

There was a treatment $\times$ sampling time interaction for percentage $\mathrm{CD}^{+}(P=0.0002)$ and $\mathrm{CD}^{+}(P<0.0001)$ lymphocytes. On d 2 , percentage $\mathrm{CD} 4^{+}$and $\mathrm{CD} 8^{+}$lymphocytes decreased $(P<0.001)$ in $\mathrm{W}$ and subsequently returned to baseline $(P>0.05)$, whereas $C$ did not differ $(P>0.05)$ from baseline (Figure 1a and 1b). There was no effect of treatment $(P=0.3)$ or treatment $\times$ sampling time interaction $(P=0.6)$ for CD4: CD8 ratio. Sampling time was significant $(P=0.005)$, whereby CD4: CD8 ratio increased $(P=0.05)$ on $\mathrm{d} 7$ compared with baseline (Figure 1c).

There was a treatment $\times$ sampling time interaction for $\mathrm{WC1}^{+}(P<0.001)$ and MHC Class $\mathrm{II}^{+}(P=0.002)$ lymphocytes. On $\mathrm{d} 2$, the percentage $\mathrm{WC}^{+}$lymphocytes decreased $(P<0.005)$ in $\mathrm{W}$ and $\mathrm{C}$, however the decrease was greater $(P=0.008)$ in W (Figure 2a). Subsequently, the percentage $\mathrm{WC}^{+}$lymphocytes returned to baseline in both treatments $(P>0.05)$. Conversely, on $\mathrm{d} 2$, percentage MHC Class $\mathrm{II}^{+}$lymphocytes increased $(P<0.01)$ in $\mathrm{W}$ and $\mathrm{C}$ but the increase was greater $(P=0.002)$ in
$\mathrm{W}$ than $\mathrm{C}$, before returning to baseline $(P=0.3)$ (Figure $2 b)$.

\section{Acute phase proteins}

There were no effects $(P>0.05)$ of treatment or treatment $\times$ sampling time interactions for plasma fibrinogen and haptoglobin concentrations. Sampling time was significant $(P=0.0002)$ for haptoglobin, whereby on $\mathrm{d} 2$, concentration increased $(P=0.01)$ compared with baseline (means (s.e.) $0.48(0.033) \mathrm{mg} / \mathrm{mL}$ versus $0.32(0.023)$ $\mathrm{mg} / \mathrm{mL})$. Sampling time was not significant $(P=0.3)$ for fibrinogen concentration (data not shown).

\section{Discussion}

The immune variables measured in the present study showed that weaning together with movement of beef calves from a pasture environment to a housing environment elicited transient neutrophilia, impaired neutrophil phagocytic function, decreased peripheral lymphocyte count and altered immunophenotypes. To the authors' knowledge, this is the first study to collectively examine these immune responses to weaning and housing in the beef calf.

Stress-induced changes in immune function have been documented in cattle, with alterations to cell-mediated and humoral immunity having a significant impact on

Table 3 Effect of abruptly weaning at housing on phagocytic and oxidative burst positive neutrophils in beef calves

\begin{tabular}{|c|c|c|c|c|c|c|c|c|c|}
\hline \multirow[b]{2}{*}{ Neutrophils, \% } & & \multicolumn{5}{|c|}{ Days (d) relative to housing } & \multicolumn{3}{|c|}{$P$-values ${ }^{1}$} \\
\hline & & -7 & $0^{2}$ & 2 & 7 & 14 & $\mathrm{~T}$ & $\mathrm{~S}$ & $\mathrm{~T} \times \mathrm{S}$ \\
\hline \multirow[t]{2}{*}{ Phagocytosis positive } & C & $87.2 \pm 2.00$ & $88.8 \pm 1.98$ & $79.4^{x} \pm 3.20$ & $87.4 \pm 2.48$ & $89.6 \pm 2.18$ & 0.003 & $<0.0001$ & 0.02 \\
\hline & W & $87.0 \pm 2.00$ & $89.6^{\mathrm{a}} \pm 1.98$ & $61.3^{b, y} \pm 3.20$ & $79.7^{\mathrm{a}} \pm 2.48$ & $89.3^{a} \pm 2.18$ & & & \\
\hline \multirow[t]{2}{*}{ Oxidative burst positive } & C & $36.5 \pm 3.93$ & $36.6 \pm 2.14$ & $45.1 \pm 4.83$ & $46.1 \pm 5.24$ & $40.3 \pm 5.82$ & 0.5 & 0.2 & 0.7 \\
\hline & W & $34.7 \pm 3.93$ & $37.0 \pm 2.14$ & $41.3 \pm 4.83$ & $37.2 \pm 5.24$ & $40.1 \pm 5.82$ & & & \\
\hline
\end{tabular}

${ }^{1} \mathrm{~T}=$ treatment, $\mathrm{S}=$ sampling time, $\mathrm{T} \times \mathrm{S}=$ treatment $\times$ sampling time interactions.

$\mathrm{W}=$ abruptly weaned, $\mathrm{C}=$ non-weaned (control) calves.

a, b, cWithin a row, least squares means without a common superscript differ $(P=0.01)$.

$\mathrm{x}, \mathrm{y}$ Within a column (day) for each variable, least squares means without a common superscript differ $(P=0.03) .{ }^{2}$ Baseline is defined as $\mathrm{d} 0$ for each variable. Data presented are least squares means \pm s.e.m. 
a)

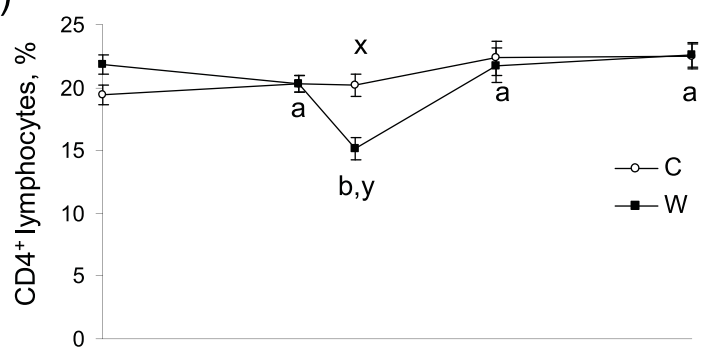

b)

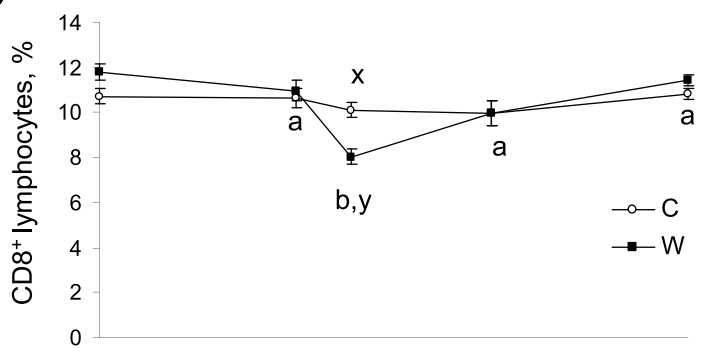

c)

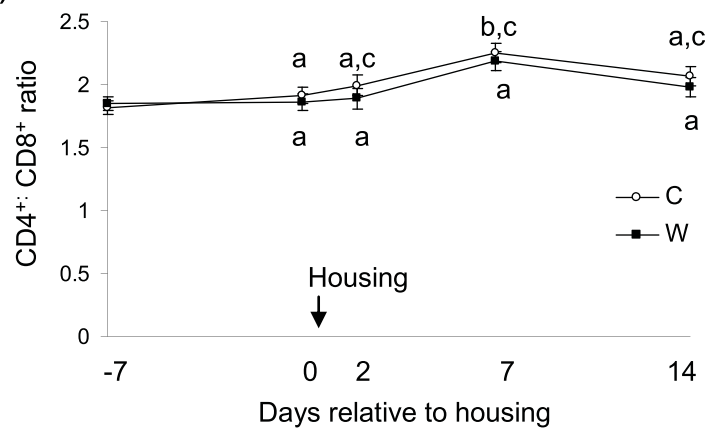

Figure 1 Effect of abrupt weaning at housing on percentage a) $\mathrm{CD}^{+}$and b) $\mathrm{CD}^{+}$lymphocytes (least squares mean \pm s.e.m., $\%$ ) and c) CD4: CD8 ratio (least squares means \pm SEM) in beef calves. $W=$ abruptly weaned calves, $C=$ non-weaned (control) calves. ${ }^{a}$, b, cBetween days, least squares means without a common superscript differ $(P<0.05)$. ${ }^{x}$ y Within a day, least squares means without a common superscript differ $(P<0.05)$. $T \times S=$ treatment $\times$ sampling time point interaction. Baseline is defined as $\mathrm{d} 0$ for each variable.

immunocompetence which may render an animal more susceptible to infection [19-22]. In the present study, neutrophil surveillance and phagocytic activity were affected by weaning, however bactericidal activity was unaffected. Post-weaning, peripheral neutrophil count increased which was most likely resultant of the decreased surface expression of L-selectin as defined by the reduced MFI CD62L on blood neutrophils. Reduction of this adhesion molecule from the surface of neutrophils, where it is constitutively expressed on resting cells prior to activation, suggests that weaning may have
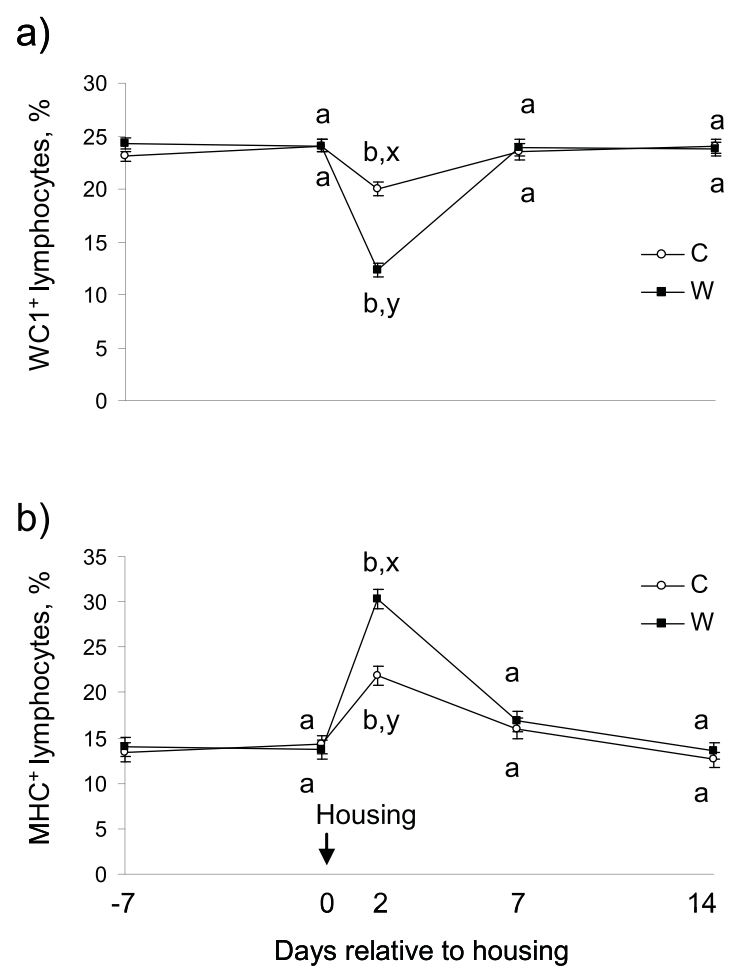

Figure 2 Effect of abrupt weaning at housing on a) $\mathrm{WC1}^{+}$and b) MHC Class II lymphocytes (least squares mean \pm s.e.m., \%) in beef calves. $\mathrm{W}=$ abruptly weaned calves, $\mathrm{C}=$ non-weaned (control) calves. a, b, cBetween days, least squares means without a common superscript differ $(P<0.001)$. ${ }^{x}$. $y$ Within a day, least squares means without a common superscript differ $(P<0.01)$. $T \times S=$ treatment $\times$ sampling time point interaction. Baseline is defined as d 0 for each variable.

had a negative impact on the ability of these cells to roll along and adhere to the endothelium lining of blood vessels and thus, more cells remained in circulation as evidenced by neutrophilia. This phenomenon has been documented in physiologically stressed cattle, most notably coinciding with parturition [23-25] and following transportation [26].

Additionally, weaned calves had reduced percentage of neutrophils performing phagocytosis compared with control calves. This transient depression in phagocytosis was short lived with cells recovering this function by 7 $\mathrm{d}$ post-housing. This finding concurs with the other findings that report a transient decrease in neutrophil phagocytic activity in weaned foals [27]. Decreased phagocytosis has also been reported in horses following transportation [28], in cows that were milked only oncea-day [29], and in dairy cattle following administration of ACTH and dexamethasone [30-32]. Although phagocytic activity of neutrophils was impaired immediately post-weaning, the ability of these cells to perform oxidative burst activity was unaffected, implying that any 
internalised particles or bacteria could be efficiently degraded despite the depression in particle uptake by neutrophils. Unaltered respiratory burst activity was reported in 14 mo old Holstein-Friesian bulls that were subjected to either Burdizzo castration or hydrocortisone infusion [33]. Moreover, in vitro studies examining pharmacological high doses of infused hydrocortisone and therapeutic doses of glucocorticoids did not affect the oxidative burst activity of neutrophils isolated from high milk yielding Holsteins 2 - 5 weeks postpartum [34].

Appropriate lymphocyte responses provide immunoprotection against bacterial and viral antigens but can also critically influence immunopathogenesis of disease [35-37]. In agreement with other studies [6,7,38], weaning decreased peripheral lymphocyte count. Further investigation of the lymphocyte immunophenotypes showed that there was a greater reduction in the percentage of $\gamma \delta \mathrm{T}$ cells than $\alpha \beta \mathrm{T}$ cells post-weaning. Transient decreases in proportion of $\mathrm{WC1}^{+}$lymphocytes were observed in both treatment groups, with the greatest degree of change observed when weaning and housing were combined. Calves held in conventional housing had significantly lower percentage $\mathrm{WC1}^{+} \mathrm{T}$ cells compared with calves that were allowed free-range grazing and access to their dams [39]. Moreover, a decrease in $\mathrm{WC1}^{+} \mathrm{T}$ cells in the free-ranging calves coincided with a change from an outdoor to indoor environment following a period of transportation. Contrary to the present findings, percentage $\mathrm{WC}^{+} \mathrm{T}$ cells did not return to baseline in that study, rather they remained decreased and after 3 weeks post-housing were not different from calves that were permanently housed [39]. The additional stressor of transportation may have contributed to the prolonged response observed in the latter study. Our findings are in agreement with other studies which have shown that $\gamma \delta \mathrm{T}$ cells are most sensitive to physiological and pharmacological stressors with reductions in percentage $\mathrm{WC1}^{+}$lymphocytes observed following transportation of beef steers [14], parturition in dairy cows [40] and dexamethasone treatment in dairy and beef bulls $[41,42]$.

In the present study, the decrease in percentage $\alpha \beta \mathrm{T}$ cells post-weaning was evidenced by transient decreases in percentage $\mathrm{CD} 4^{+}$and $\mathrm{CD} 8^{+}$lymphocytes. Decreases in both peripheral $\mathrm{CD}_{4}^{+}$and $\mathrm{CD} 8^{+}$lymphocytes have been reported in calves at unloading after $14 \mathrm{~h}$ truck transportation, following which they returned to pretransport values by $24 \mathrm{~h}$ [14], and in beef steers following induction into a feedlot environment [43]. Some studies examining the effect of stress in domestic animals have utilised the $\mathrm{CD} 4^{+}: \mathrm{CD} 8^{+}$ratio as an indicator of stress-induced immunosuppression, however conflicting evidence exists in cattle [44-47]. Our findings showed that movement of beef calves from a pasture environment to a housing environment was able to elicit a transient increase in $\mathrm{CD} 4^{+}: \mathrm{CD}^{+}$ratio. This increase may reflect recovery of immune competence in an attempt to restore homeostasis following the initial reaction to the onset of stress. An overall rise in $\mathrm{CD}^{+}: \mathrm{CD}^{+}$ratio was reported in sheep that were housed either in isolation or in groups [47]. These authors attributed the rise in CD4 ${ }^{+}: \mathrm{CD}^{+}$ratio to recovery of immune compensation following perturbation to lymphocyte subsets due to a stressful change in the environment. Thus, $\mathrm{CD} 4^{+}: \mathrm{CD}^{+}$ ratio may provide more information on the recovery of homeostasis rather than occurrence of immunosuppression. Further research into the utility of this ratio to describe a stress scenario in domestic animals is warranted.

In the present study, percentage $\mathrm{MHC}$ class $\mathrm{II}^{+}$lymphocytes in peripheral blood increased significantly in weaned calves and to a lesser extent in control calves indicating that a change in environment in combination with and without weaning resulted in the activation of lymphocytes. This increase in percentage $\mathrm{MHC}$ class $\mathrm{II}^{+}$ lymphocytes may be due to increased B cells or activated $\mathrm{T}$ cells in circulation [48]. Increase in MHC class $\mathrm{II}^{+}$lymphocytes may be due to expansion of NK cells bearing MHC class II molecules [49], however, this supposition cannot be confirmed by the findings of the present study as NK cells were not investigated. Our findings concur with Riondato et al. (2008) [14] who reported increased percentage $\mathrm{MHC}$ class $\mathrm{II}^{+}$cells in transported beef steers, but in that study the response was more prolonged ( $7 \mathrm{~d}$ ). Holstein bulls challenged with pharmacological doses of dexamethasone were reported to have increased percentage $\mathrm{MHC}$ class $\mathrm{II}^{+}$ cells compared with non-treated controls [50]. Furthermore, increased percentage $\mathrm{MHC}$ class $\mathrm{II}^{+}$lymphocytes have been reported following repeated restraint and isolation stress in lambs [51].

The reduction in lymphocyte subsets is most likely attributable to a redistribution of these cells from the peripheral circulation to immune compartments or tissues of greater importance during a stressful event. Trafficking of cells is an important and dynamic factor for effective cell-mediated immunity and stress has been shown to influence this process [52-54].

It is important to note that despite the numerous changes in leukocyte counts, neutrophil function and lymphocyte immunophenotypes observed, generally these perturbations were transient and homeostasis was restored by $7 \mathrm{~d}$ post-weaning. Additionally, changes in some of the immune-related biomarkers, namely the proportion of $\gamma \delta \mathrm{T}$ cells and MHC class $\mathrm{II}^{+}$cells in peripheral circulation and the phagocytic function of blood neutrophils, were evident following change in 
environment alone. Further research is warranted to investigate the potential use of these measures as prognostic biomarkers of stress sensitive and consequently, infection susceptible animals in response to other stressors.

In line with the previous study, total leukocyte count increased following weaning [6]. Monocyte, basophil and eosinophil counts were not sensitive to weaning or change in environment as evidenced by the unaltered profiles pre- and post-weaning.

Previous studies have shown that weaning induces an acute phase protein response in beef calves $[9,55,56]$, whereas in the present study, although there was a numerical increase in fibrinogen and haptoglobin concentration, it was not statistically significant. Increased and unchanged concentration of fibrinogen and haptoglobin, respectively in weaned bull calves has been reported [7], whereas elevated responses in weaned steers have been reported for fibrinogen $[6,55]$ and haptoglobin $[8,9,55]$.

\section{Conclusions}

Abrupt weaning at housing affected total leukocyte, neutrophil and lymphocyte counts, lymphocyte immunophenotypes and functional activity of neutrophils in beef calves. Neutrophilia was evident post-weaning, however, crucially, the functional capacity of these cells to effectively traffic from the periphery and phagocytose bacteria was temporarily decreased. Additionally, weaning resulted in a temporary reduction in lymphocyte subsets, most notably of $\gamma \delta$ lymphocytes. Considered together, abrupt weaning transiently impaired immune function in beef calves and thus, in terms of immunocompetence, weaning management strategies with the potential to minimise stress in beef calves should be considered.

\section{Methods}

All animal procedures performed in this study were conducted under experimental licence from the Irish Department of Health and Children in accordance with the Cruelty to Animals Act 1876 and the European Communities (Amendment of Cruelty to Animals Act 1876) Regulation 2002 and 2005.

\section{Animal management and experimental design}

Sixteen, spring-born (mean date of birth (s.d); 23 March (18.2) d) single-suckled, castrated, male calves of Limousin $\times$ Holstein-Friesian and Simmental $\times$ Holstein-Friesian dams and Simmental and Limousin sires, respectively, were used in this study. Cows and calves were rotationally grazed together on a predominantly perennial ryegrass-based sward from April until housing in a slatted floor shed at the end of the grazing season (13 November). On the day of housing (d 0$)$, calves were moved to a handling yard adjacent to the paddock. Calves (mean age (s.d.) 235 (18.2) d; mean weight (s.d.) $310(31.1) \mathrm{kg}$ ) were blocked by genotype, age, and weight and then randomly assigned within block to one of two treatments (i) abruptly weaned (W; $\mathrm{n}=8$ ) or (ii) non-weaned (control) $(\mathrm{C} ; \mathrm{n}=8$ ). Weaned calves were housed in pens without their dams (4 calves per pen), whereas non-weaned (control calves) were housed with their dams (2 cow-calf pairs per pen). Space allowance within the pens was equal for animals. Pens were equipped with automatic drinkers and animals were offered grass silage ad libitum. Cows that were separated from their calves were housed and had no auditory or visual contact with their calves.

\section{Rectal Body Temperature}

Rectal body temperature of calves was recorded before blood sampling on $\mathrm{d}-7,0$ (housing), 2, 7, and 14 using a digital thermometer (Jørgen Kruuse; Marslev, Denmark).

\section{Blood Collection}

Blood was collected into vacutainers (Vacuette, Cruinn Diagnostics, Ireland), containing the appropriate anticoagulant for subsequent haematological and flow cytometric analysis via direct jugular venipuncture using mild restraint in a holding chute at day (d) -7, 0 (housing), 2, 7 and 14. Blood samples were transported to the laboratory, stored at ambient temperature and processed within $3.5 \mathrm{~h}$.

\section{Total and differential leukocyte populations}

Total leukocyte, neutrophil, lymphocyte, monocyte, eosinophil, and basophil were determined from $\mathrm{K}_{3}$ EDTA anti-coagulated blood $(6 \mathrm{~mL})$ using an automated haematology analyzer (ADVIA 2120, Bayer Healthcare, Siemens, UK) equipped with software for bovine blood.

\section{Leukocyte immunostaining}

Acid citrate dextrose anti-coagulated blood $(8 \mathrm{~mL})$ was used to for leukocyte immunostaining using a whole blood assay [57]. Briefly, duplicate $1 \mathrm{~mL}$ aliquots of whole blood were transferred to a $5 \mathrm{~mL}$ test tube (Sarstedt, Nümbreacht, Germany) and tubes were centrifuged at $250 \times g$ for 5 mins at $4^{\circ} \mathrm{C}$. After aspiration of supernatants, $3 \mathrm{~mL}$ of BD FACS lysing solution (BD Biosciences, Oxford, UK) was added for 10 mins at room temperature to lyse erythrocytes. Remaining leukocytes were resuspended in $1.5 \mathrm{~mL}$ of sheath fluid (Coulter Isoton II Diluent (Beckman Coulter UK Ltd., High Wycombe, UK) and counted using a Z1 Coulter Particle Counter (LABPLAN Ltd., Galway, Ireland). One hundred microliter aliquots of cell suspension $\left(1 \times 10^{6}\right.$ cells $)$ were seeded into series 
of wells on a 96-well microtiter plate. Leukocyte immunostaining was carried out using a 2-antibody system, as described by [41], with the exception of the secondary (detection) antibody where FITC-labelled goat antimouse IgG F(ab')2 (Southern Biotech, Birmingham, AL, USA) was used following a 1/100 dilution with PBS-0.01 $(\mathrm{w} / \mathrm{v}) \%$ BSA. Sources, specificities, isotypes and working solutions of monoclonal and secondary antibodies are described in Table 4. All antibodies were diluted to final working concentration using PBS-0.01\% (w/v) BSA (pH 7.2). Following this procedure, cells were fixed with 200 $\mu \mathrm{l}$ of $1 \%(\mathrm{v} / \mathrm{v})$ paraformaldehyde, and further diluted with $800 \mu \mathrm{l}$ of sheath fluid for immediate acquisition on a Partec CyFlow SL flow cytometer (Partec, Münster, Germany). Cells were kept at $4{ }^{\circ} \mathrm{C}$ in the dark prior to acquisition.

\section{Phagocytic and oxidative burst activity assays}

The phagocytic and oxidative burst activity of neutrophils was determined in lithium heparin anti-coagulated blood $(8 \mathrm{~mL}$ ) using the Phagotest kit and Bursttest (PhagoBurst) kit (Orpegen Pharma, Heidelberg, Germany) following the manufacturer's instructions, with modifications [58], on a Partec CyFlow SL flow cytometer (Partec Gmbh, Münster, Germany). Duplicate tests for each sample were performed.

\section{Flow cytometric analysis}

Immunophenotypes. A minimum of 30,000 events were acquired and analyzed using FloMax software (Partec $\mathrm{GmbH}$, Münster, Germany). Lymphocytes and neutrophils were gated from all other leukocyte populations based on their forward and side scatter characteristics on dot plots and were confirmed using CD45 (pan leukocyte) staining [59]. The percentage lymphocytes staining positive for $\mathrm{CD} 4, \mathrm{CD} 8, \mathrm{WC1}$, and $\mathrm{MHC}$ class II, and percentage of neutrophils staining positive for G1 was recorded. Surface expression of CD62L was recorded as mean fluorescence intensity (MFI) of CD62L-staining positive neutrophils. A threshold for positive staining cells was set using histograms identifying irrelevant isotype controls and PBS-0.01 (w/v) \% BSA only treated leukocytes.

Phagocytic and oxidative burst activity assays. Data were acquired from 15,000 cells per sample and analysis was carried out using FloMax software (Partec Gmbh, Münster, Germany). For each sample, the percentage phagocytosis positive and oxidative burst positive cells within the neutrophil gate were recorded.

\section{Acute phase protein response (fibrinogen and haptoglobin)}

Blood collected into vacutainer tubes containing lithium heparin $(8 \mathrm{~mL})$ and sodium citrate $(4.5 \mathrm{~mL})$ was used to determine the concentration of haptoglobin and fibrinogen, respectively. Plasma was harvested following centrifugation at $1600 \times g$ at $4^{\circ} \mathrm{C}$ for $15 \mathrm{~min}$ and stored at $-80^{\circ} \mathrm{C}$ until assayed. Concentration of plasma haptoglobin was measured using an automatic analyzer (spACE, Alfa Wassermann, Inc., West Caldwell, NJ, USA) and commercial assay kit (Tridelta Development Ltd., Wicklow, Ireland) according to the manufacturer's procedure as described by [60]. Concentration of fibrinogen was measured using an automatic analyzer (spACE, Alfa Wassermann, Inc., West Caldwell, NJ, USA) using a previously described method [61].

\section{Statistical Analysis}

All statistical analysis was performed using SAS/STAT for Windows [62]. Data were tested for normality using PROC UNIVARIATE, and data (neutrophil G1 data only) that did not meet parametric assumptions were transformed by a square root transformation prior to statistical analysis. Data were then analyzed as repeated measures using the PROC MIXED procedure of SAS with an unstructured covariance matrix within animal. The effects of treatment, sampling time, genotype and all possible interactions were listed in the model statement. Genotype was not significant $(P>0.05)$ and was not included in the model. Day -7 was included as a covariate but this was not significant $(P>0.05)$ and was omitted from the model. Baseline is defined as day 0 for

Table 4 Antibodies used in the immunostaining of leukocyte surface markers in beef calves

\begin{tabular}{|c|c|c|c|c|c|}
\hline Specificity & Cell types & Clone & Isotype & Working solution & Source $^{1}$ \\
\hline CD4 & T-helper/inducer cells & CC8 & $\lg G_{2} \mathrm{a}$ & $7 \mu \mathrm{L} / \mathrm{mL}$ & Serotec \\
\hline CD8 & T-cytotoxic/suppressor cells & CC63 & $\lg _{2} \mathrm{a}$ & $7 \mu \mathrm{L} / \mathrm{mL}$ & Serotec \\
\hline WC1 & Subset of $\gamma \delta$ T cells & CC15 & $\lg _{2} \mathrm{a}$ & $7 \mu \mathrm{L} / \mathrm{mL}$ & Serotec \\
\hline MHC class $\|$ & Antigen presenting cells (B cells, activated T cells) & $\mathrm{H} 42 \mathrm{~A}$ & $\lg G_{2} \mathrm{a}$ & $7 \mu \mathrm{L} / \mathrm{mL}$ & VMRD \\
\hline CD62L & L-selectin & BAQ92A & $\lg G_{1}$ & $14 \mu \mathrm{L} / \mathrm{mL}$ & VMRD \\
\hline G1 & Neutrophils (and eosinophils) & MM20A & $\lg G_{1}$ & $14 \mu \mathrm{L} / \mathrm{mL}$ & VMRD \\
\hline CD45 & All leukocytes (pan marker) ${ }^{2}$ & $\mathrm{CC} 1$ & $\lg G_{1}$ & $3.5 \mu \mathrm{L} / \mathrm{mL}$ & Serotec \\
\hline
\end{tabular}

${ }^{1}$ Serotec (Oxford, UK), VMRD (Pullman, WA, USA).

${ }^{2}$ Used to differentiate leukocyte populations and exclude debris (gate analysis). 
each variable in the description of the results and representation of the data. Least squares means were estimated, differences between least squares means were determined using the Tukey-Kramer test for multiple comparisons, and the associated $P$-values presented were derived from the statistical analysis of the data using the model described above. A probability of $P<0.05$ was selected as the level of significance.

\section{Acknowledgements}

This study was supported by a Teagasc Walsh Fellowship to E. M. Lynch. The authors thank E. Mulligan and P. Lawrence (Teagasc, Grange Beef Research Centre) for their excellent technical assistance with blood sample collection, and M. Murray (Teagasc Animal, Grassland and Bioscience Research Centre) and J. Larkin (Teagasc, Grange Beef Research Centre) for their excellent technical assistance with haematological and flow cytometric analysis, respectively. Many thanks are due to the farm staff at Teagasc, Grange Beef Research Centre for the care and management of the animals. E. M. Lynch was a recipient of a Teagasc Walsh Fellowship and a John and Pat Hume Scholarship, National University of Ireland, Maynooth, Ireland.

\section{Author details}

${ }^{1}$ Animal and Bioscience Research Department, Animal \& Grassland Research and Innovation Centre, Teagasc, Grange, Dunsany, Co Meath, Ireland. ${ }^{2}$ Department of Biology and National Institute for Cellular Biotechnology, National University of Ireland Maynooth, Co. Kildare, Ireland. ${ }^{3}$ Livestock Systems Research Department, Animal \& Grassland Research and Innovation Centre, Teagasc, Grange, Dunsany, Co Meath, Ireland.

\section{Authors' contributions}

$B E$ and $M M C G$ designed the study. EML and BE performed the experiments. $B E$ and $E M L$ analysed the data and EL prepared the manuscript. EML, BE, MMcG and SD contributed to, read and approved the final manuscript.

Received: 2 March 2010 Accepted: 22 July 2010 Published: 22 July 2010

\section{References}

1. Drennan MJ, McGee M: Performance of spring-calving beef suckler cows and their progeny to slaughter on intensive and extensive grassland management systems. Livest Sci 2009, 120:1-12.

2. Duff GC, Galyean ML: BOARD-INVITED REVIEW: Recent advances in management of highly stressed, newly received feedlot cattle. J Anim Sci 2007, 85:823-840.

3. Price EO, Harris JE, Borgwardt RE, Sween ML, Connor JM: Fenceline contact of beef calves with their dams at weaning reduces the negative effects of separation on behaviour and growth rate. J Anim Sci 2003, 81:116-121.

4. Haley DB, Bailey DW, Stookey JM: The effects of weaning beef calves in two stages on their behavior and growth rate. J Anim Sci 2005, 83:2205-2214.

5. Lefcourt AM, Elsasser TH: Adrenal responses of Angus $\times$ Hereford cattle to stress of weaning. J Anim Sci 1995, 73:2669-2676.

6. Blanco M, Casasús I, Palacio J: Effect of age at weaning on the physiological stress response and temperament of two beef cattle breeds. Animal 2009, 3:108-117.

7. Hickey MC, Drennan M, Earley B: The effect of abrupt weaning of suckler calves on the plasma concentrations of cortisol, catecholamines, leukocytes, acute phase proteins and in vitro interferon-gamma production. J Anim Sci 2003, 81:2847-2855.

8. Arthington D, Spears JW, Miller DC: The effect of early weaning on feedlot performance and measures of stress in beef calves. $J$ Anim Sci 2005, 83:933-939.

9. Arthington DJ, Qui X, Cooke RF, Vendramini JMB, Araujo DB, Chase CC Jr, Coleman SW: Effects of preshipping management on measures of stress and performance of beef steers during feedlot receiving. J Anim Sci 2008, 86:2016-2023.

10. Callan RJ, Garry FB: Biosecurity and bovine respiratory disease. Vet Clin Food Anim Pract 2002, 18:57-77.
11. Snowder GD: Genetics, environment and bovine respiratory disease. Anim Health Res Rev 2009, 10:117-119.

12. Paape MJ, Bannerman DD, Zhao X, Lee JW: The bovine neutrophil: Structure and function in blood and milk. Vet Res 2003, 34:597-627.

13. Janeway CA, Travers M, Walport M, Shlomchik MJ: Immunobiology, the immune system in health and disease. Garland Science Publications, New York, 62005.

14. Riondato F, D'Angelo A, Miniscalco B, Bellino C, Gugliemino R: Effects of road transportation on lymphocyte subsets in calves. Vet J 2008, 175:364-368.

15. Buckham Sporer KR, Burton JL, Earley B, Crowe MA: Transportation stress in young bulls alters expression of neutrophil genes important for the regulation of apoptosis, tissue remodelling, margination, and antibacterial function. Vet Immunol Immunopathol 2007, 118:19-29.

16. Mclnnes E, Sopp P, Howard CJ, Taylor G: Phenotypic analysis of local cellular responses in calves infected with bovine respiratory syncytial virus. Immunology 1999, 96:396-403.

17. Coomber BL, Nyarko KA, Noyes TM, Gentry PA: Neutrophil-platelet interactions and their relevance to Bovine Respiratory Disease. Vet $J$ 2001, 161:41-62

18. Sandbulte MR, Roth JA: T-cell populations responsive to bovine respiratory syncytial virus in seronegative calves. Vet Immunol Immunopathol 2002, 84:111-123.

19. Kelley KW: Stress and immune function: A bibliographic review. Ann Rech Vet 1980, 11:445-478.

20. Griffin JFT: Stress and immunity: a unifying concept. Vet Immunol Immunopathol 1989, 20:263-312.

21. Chirase NK, Greene W, Purdy CW, Loan RW, Auvermann BW, Parker DB, Walborg EF, Steveson DE, XU Y, Klauing JE: Effect of transportation stress on respiratory disease, serum antioxidant status, and serum concentrations of lipid peroxidase biomarkers in beef cattle. Am J Vet Res 2004, 65:860-864.

22. Carroll JA, Forsberg NE: Influence of stress and nutrition on cattle immunity. Vet Clin North Am Food Anim Pract 2007, 23:105-150.

23. Lee EK, Kehrli ME Jr: Expression of adhesion molecules on neutrophils of peri-parturient cows and neonatal calves. Am J Vet Res 1998, 59:37-43.

24. Monfardini E, Paape MJ, Wang Y, Capuco AV, Husheem M, Wood L, Burvenich C: Evaluation of L-selectin expression and assessment of protein tyrosine phosphorylation in bovine polymorphonuclear neutrophil leukocytes around parturition. Vet Res 2002, 33:271-281.

25. Burton JL, Madsen SA, Chang LC, Weber PSD, Buckham KR, van Dorp R, Hickey MC, Earley B: Gene expression signatures in neutrophils exposed to glucocorticoids: A new paradigm to help explain "neutrophil dysfunction" in parturient dairy cows. Vet Immunol Immunopathol 2005, 105:197-219.

26. Yagi Y, Shiono H, Chikayama Y, Ohnuma A, Nakamura I, Yayou K: Transport stress increases somatic cell counts in milk, and enhances the migration capacity of peripheral blood neutrophils in dairy cows. J Vet Med Sci 2004, 66:381-387.

27. Sarwar $\mathrm{A}$, Budde $\mathrm{V}$, Enbergs $\mathrm{H}$ : Effects of weaning on polymorphonuclear cells phagocytic activity, lymphocyte proliferation and serum IgAconcentration in foals. Veterinarski Arhiv 2008, 78:1-11.

28. Raidal SL, Bailey GD, Love DN: Effect of transportation on lower respiratory tract contamination and peripheral blood neutrophil function. Aust Vet J 1997, 75:433-438.

29. Llamas Moya S, Alonso Goméz M, Boyle LA, Mee JF, O'Brien B, Arkins S: Effects of milking frequency on phagocytosis and oxidative burst activity of phagocytes from primiparous and multiparous dairy cows during early lactation. J Dairy Sci 2008, 91:587-595.

30. Paape MJ, Gwazdaskas FC, Guirdy AJ, Weinland BT: Concentrations of corticosteroids, leukocytes, and immunoglobulins in blood and milk after administration of ACTH to lactating dairy cattle: Effects of phagocytosis of Staphylococcus aureus by polymorphonuclear leukocytes. Am J Vet Res 1981, 42:2081-2087.

31. Roth $J A$, Kaeberle ML: Effects of in vivo dexamethasone administration on in vitro bovine polymorphonuclear leukocyte function. Infect Immun 1981, 33:434-441.

32. Roth JA, Kaeberle ML, Hsu WH: Effect of ACTH administration on bovine polymorphonuclear leukocyte function and lymphocyte blastogenesis. Am J Vet Res 1982, 43:412-216. 
33. Pang WY, Earley B, Sweeney T, Pirani S, Gath V, Crowe MA: Effects of banding or burdizzo castration of bulls on neutrophil phagocytosis and respiratory burst, CD62-L expression, and serum interleukin-8 concentration. J Anim Sci 2009, 87:3187-3195.

34. Hoeben D, Burvenich C, Massart-Leen AM: Glucocorticoids and in vitro effects of chemiluminescence of isolated bovine blood granulocytes. Eur J Pharmacol 1998, 345:197-203.

35. Glaser R, Kiecolt-Glaser JK: Stress-induced immune dysfunction: implications of health. Nat Rev Immunol 2005, 5:243-251.

36. Gershwin L: Bovine respiratory syncytial virus infection: immunopathogenic mechanisms. Anim Health Res Rev 2007, 8:207-213.

37. Salak-Johnson JL, McGlone JJ: Making sense of conflicting data: Stress and immunity in swine and cattle. J Anim Sci 2007, 85:E81-E88.

38. Lynch EM, Earley B, McGee M, Doyle S: Effect of weaning strategy on immunological, hematological and physiological responses of beef calves. J Anim Sci E Supp/ 2008, 89:156.

39. Baldwin CL, Sathiyaseelan T, Rocchi M, McKeever D: Rapid changes occur in the percentage of circulating $\mathrm{WC}^{+} \gamma \delta$ Th1 cells. Res Vet Commun 2000, 69:175-180.

40. Meglia G, Johannisson A, Agenäs S, Holtenius K, Persson Waller K: Effects of feeding intensity during dry period on leukocytes and lymphocyte subpopulations, neutrophil function and health in periparturient dairy cows. Vet J 2005, 169:376-384.

41. Burton JL, Kehrli ME Jr: Effects of dexamethasone on bovine circulating $T$ lymphocyte populations. J Leukoc Biol 1996, 59:90-99.

42. Menge C, Dean-Nystrom EA: Dexamethasone depletes $\gamma \delta$ T cells and alters the activation state and responsiveness of bovine peripheral blood lymphocytes subpopulations. J Dairy Sci 2008, 91:2284-2298.

43. Fell LR, Colditz IG, Walker KH, Watson DL: Associations between temperament, performance and immune function in cattle entering a commercial feedlot. Aust J Exp Agri 1999, 39:795-802.

44. Van Kampen C, Mallard BA: Effects of peripartum stress and health on circulating bovine lymphocyte subsets. Vet Immunol Immunopathol 1997, 59:79-91.

45. Anderson $\mathrm{BH}$, Watson $\mathrm{DL}$, Colditz IG: The effect of dexamethasone on some immunological parameters in cattle. Vet Res Commun 1999, 23:399-413.

46. Ishizaki $H$, Hanafusa $Y$, Kariya $Y$ : Influence of truck-transportation on the function of bronchoalveolar lavage fluid cells in cattle. Vet Immunol Immunopathol 2005, 105:67-74.

47. Degabriele R, Fell LR: Changes in behaviour, cortisol and lymphocyte types during isolation and group confinement of sheep. Immunol Cell Biol 2001, 79:583-589.

48. Quade MJ, Roth JA: Dual-color flow cytometric analysis of phenotype, activation marker expression, and proliferation of mitogen-stimulated bovine lymphocyte subsets. Vet Immunol Immunopathol 1999, 67:33-45.

49. Storset AK, Kulberg S, Berg I, Boysen P, Hope JC, Dissen E: NKp46 defined a subset of bovine leukocytes with natural killer cell characteristics. Eur J Immunol 2004, 34:669-676.

50. Saama PM, Jacob JB, Kehrli ME Jr, Freeman AE, Kelm SC, Kuck AL, Templeman RJ, Burton JL: Genetic variation in bovine mononuclear leukocyte responses to dexamethasone. J Dairy Sci 2004, 87:3928-3937.

51. Minton JE, Coppinger TR, Reddy PG, Davis WC, Blecha F: Repeated restraint and isolation stress alters adrenal and lymphocyte functions and some leukocyte differentiation antigens in lambs. J Anim Sci 1992, 70:1126-1132.

52. Kehrli ME, Burton JL, Nonnecke BJ, Lee EK: Effects of stress on leukocyte trafficking and immune responses: implications for vaccination. Adv Vet Med 1999, 41:61-81.

53. Bauer ME, Perks P, Lightman SL, Shanks N: Are adhesion molecules involved in stress-induced changes in lymphocytes distribution? Life Sci 2001, 69:1167-1179.

54. Viswanathan K, Dhabhar FS: Stress-induced enhancement of leukocyte trafficking into sites of surgery or immune activation. Proc Natl Acad SCi USA 2005, 102:5808-5813.

55. Arthington D, Eicher SD, Kunkle WE, Martin FG: Effect of transportation and commingling on the acute-phase protein response, growth, and feed intake of newly weaned beef calves. J Anim Sci 2003, 81:1120-1125.

56. Carroll JA, Arthington JD, Chase CC Jr: Early weaning alters the acutephase reaction to endotoxin challenge in beef calves. J Anim Sci 2009, 87:4167-4172.
57. Weber PSD, Madsen SA, Smith GW, Ireland JJ, Burton JL: Pre-translational regulation of neutrophil L-selectin in glucocorticoid challenged cattle. Vet Immunol Immunopathol 2001, 83:213-240.

58. Kampen AH, Tollersrud T, Larsen S, Roth JA, Frank DE, Lund A: Repeatability of flow cytometric and classical measurement of phagocytosis and respiratory burst in bovine polymorphonuclear leukocytes. Vet Immunol Immunopathol 2004, 97:105-114.

59. Pelan-Mattocks LS, Pesch BA, Kehrli ME: Flow cytometric analysis of intracellular complexity and CD45 expression for use in rapid differentiation of leukocytes in bovine blood samples. Am J Vet Res 2001, 62:1740-1744.

60. Eckersall PD, Duthie S, Safi S, Moffatt D, Horadagoda NU, Doyle S, Parton R, Bennett D, Fitzpatrick JL: An automated biochemical assay for haptoglobin: prevention of interference from albumin. Comp Haematol Int 1999, 9:117-124.

61. Becker U, Bartl K, Wahlefed AW: A functional photometric assay for plasma fibrinogen. Thromb Res 1984, 35:475-484.

62. SAS: Version 9.1 SAS Institute Inc, Cary, NC, USA 2003.

\section{doi:10.1186/1746-6148-6-39}

Cite this article as: Lynch et al: Effect of abrupt weaning at housing on leukocyte distribution, functional activity of neutrophils, and acute phase protein response of beef calves. BMC Veterinary Research 2010 6:39.

\section{Submit your next manuscript to BioMed Central and take full advantage of:}

- Convenient online submission

- Thorough peer review

- No space constraints or color figure charges

- Immediate publication on acceptance

- Inclusion in PubMed, CAS, Scopus and Google Scholar

- Research which is freely available for redistribution
C Biomed Central 